\title{
Aloe Vera Delays Mortality, but Does Not Attenuate Kidney Injury in Septic Mice
}

Vitor Nagai Yamaki ${ }^{1}$, Renan Kleber Costa Teixeira ${ }^{1}$, Eduardo Henrique Herbster Gouveia', Daniel Haber Feijo', Luan Teles Ferreira de Carvalho', Denilson José Silva Feitosa Júnior ${ }^{1}$, André Lopes Valente ${ }^{1}$, Edson Yuzur Yasojima ${ }^{1}$, Marcus Vinicius Henriques Brito ${ }^{1}$

\section{Abstract}

Background: Intensive care units (ICUs) admissions due to sepsis represent 2 to $11 \%$. Although there are well stablished therapeutic available, it still is the major cause of death in most ICUs and the leading cause of acute kidney injury. The objective of this work was to evaluate the role of Aloe vera extract on survival rates and kidney histopathology of mice submitted to sepsis induced by cecal ligation and puncture.

Methods and Findings: Twenty six mice were distributed into four groups: Sham - surgery simulation $(\mathrm{N}=5)$; Control - Cecal ligation and puncture was performed $(\mathrm{N}=7)$; Aloe - Surgery simulation and treatment with Aloe vera extract $(\mathrm{N}=7)$; and Sepsis + Aloe - Cecal ligation and puncture was performed followed by treatment with Aloe vera extract $(\mathrm{N}=7)$. The animals were observed until death. Kidneys were analysed by histopathology. Kruskall-Wallis test was used to compare the histopathological results. Survival analysis was assessed by Kaplan-Meier statistics and compared using log rank test. A significance level of $5 \%$ was adopted. The survival time ranged from 19 hours for the Control group up to 24 hours for the animals of Sepsis + Aloe group, corresponding to a survival time of 1.26 times greater $(p<0.01)$. There were no difference between the Sham and Aloe groups and between Control and Sepsis + Aloe groups according to the four parameters analyzed ( $p>0.05)$.

Conclusions: Aloe vera delays mortality but does not attenuate kidney injury.
1 Laboratory of Experimental Surgery, University of the State of Pará, Belém, Pará, Brazil.

Contact information:

Denilson José Silva Feitosa Junior.

Address: Travessa Angustura, 2969. Marco, Belém/Pará. 66093-040. Brazil.

झ denilsonfmed@gmail.com

\section{Keywords}

Aloe Vera; Medicinal Plants; Animal Models; Sepsis. 


\section{Introduction}

Intensive care units (ICUs) admissions due to sepsis represent 2 to $11 \%$ [1]. Although the great therapeutic available, it is the major cause of death in most ICUs and the leading cause of acute kidney injury $[2,3]$. The choice of antibiotics and when start support measures (such as mechanical ventilation and vasoactive drugs) is a challenge because of the difficult clinical management, caused by hemodynamic changes and electrolyte resulting from this state $[4,5]$

The "progress study" [6, 7], a multicenter trial involving 276 ICUs in 37 countries, showed higher mortality rates in Brazilian ICUs (56\%) compared to other developing countries (30\%), even though with similar populations studies. In this regard, interventions to reduce morbidity and mortality, and improve the prognosis in sepsis must be encouraged.

Medicinal plants represent an important health and economic component of biodiversity, it is used in all parts of the world and has great potential for the discovery of new active ingredients [8]. The aloe vera (Aloe barbadensismiller), popularly known in Brazil as babosa, has been used worldwide as a traditional medicine for many centuries [9]. The chemical compositions [10] of Aloe vera include glucomannans, acemannan, minerals, enzymes, inorganic compounds, flavonoid compounds, phenolic compounds that several studies [9-12] have demonstrated those has therapeutic properties as anti-inflammatory effects, wound healing, anti-diabetic activities and antioxidant effects.

We suggest employment of medicinal plants as adjuvant therapy for improvements in sepsis treatment outcomes. Therefore, we evaluated role of Aloe extract on survival rates of mice submitted to sepsis induced by cecal ligation and puncture.

\section{Methods}

After approval of the protocol by the Ethics Committee in the Use of Animals of the State University of Para (UEPA), protocol 03/15, experiments were performed in adherence with the National Institutes of Health Guidelines on the Use of Laboratory Animals. Twenty six adults males mice (Mus musculus) were used, weighing between 35-45 grams. Animals were maintained in a controlled environment, with food and water ad libitum. The animals were randomically distributed into four groups: 1) Sham group: Surgery simulation ( $\mathrm{N}=5)$; 2) Control Group: Cecal ligation and pucture was performed (CLP) $(\mathrm{N}=7)$; 3) Aloe Group: Surgery simulation and treatment with Aloe vera extract $(N=7)$; 4) Sepsis + Aloe Group: Performed CLP and treat with Aloe vera extract $(\mathrm{N}=7)$.

The animals were anesthetized with ketamine hydrochloride $(100 \mathrm{mg} / \mathrm{Kg}$ ) and xylazine hydrochloride $(10 \mathrm{mg} / \mathrm{Kg})$, intraperitoneally. We performed CLP with a predetermined $75 \%$ ligated length of cecum and a single through-and-through puncture with 21-gauge needle. This protocol is associated with a mortality of $80-100 \%$ [13] in the first postoperative day. The aloe groups were treated by Aloe vera extract $100 \mathrm{mg} / \mathrm{Kg}$, one hour after the simulation surgery or the CLP. All mices received $10 \mathrm{~mL} / \mathrm{kg}$ fluid resuscitation in the first hour with either $0.9 \%$ saline

The animals were followed until death; Confirmed these, kidneys were collect. Rat kidneys were fixed in 10\% neutral buffered formalin. Histological sections were stained with hematoxylin and eosin. It was analyzed in the kidney the presence of glomerular and tubular necrosis, tubular inflammation, parenchymal edema, hyaline and hematic casts. Histopathological analysis was ranked scores: 0 (absent), 1 (mild), 2 (moderate) and 3 (severe) [14]. Histological abnormalities were assessed by a pathologist blinded to treatment group.

Data are expressed as means \pm standard deviation. Kruskall-Wallis test was used to compare 
the histopathological results. Survival analysis was assessed by Kaplan-Meier statistics and compared using log rank test. Was adopted a significance level of $5 \%$ to reject the null hypothesis.

\section{Results}

No animals died in the Sham and Aloe groups with good surgical recovery. Survival OF 20 hours after CLP WAS favored by the treatment with Aloe vera (Aloe $7-100 \%$ vs Control $0-0 \%, p<0.01$ ). The survival time (Figure 1) ranged from 19 hours for the control group up to 24 hours for the animals of Sepsis + Aloe group, corresponding to a survival time of 1.26 times greater.

Figure 1: Graph showing the survival curve of animals.

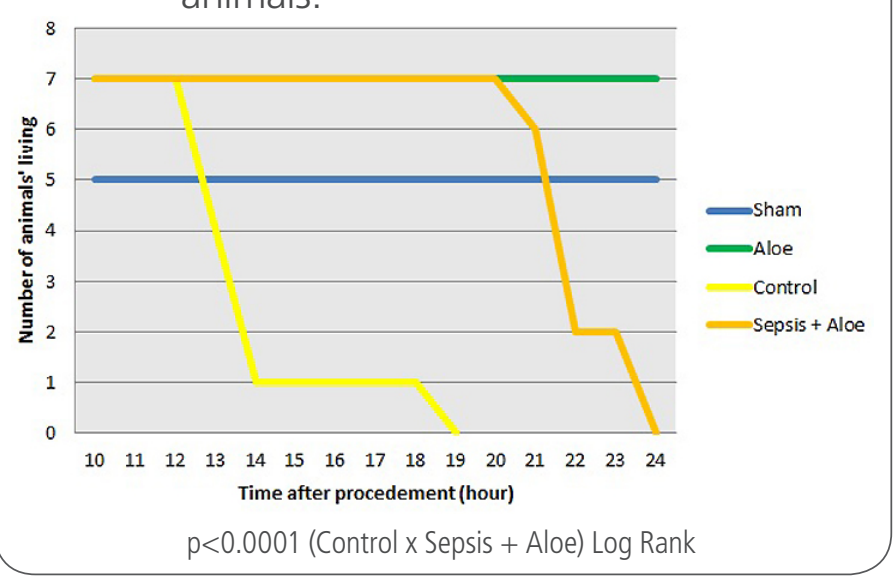

Table 1. Histopathological evaluation according each group.

\begin{tabular}{|c|c|c|c|c|}
\hline $\begin{array}{c}\text { Parameters/ } \\
\text { Group }\end{array}$ & Sham & Aloe & Control & $\begin{array}{c}\text { Sepsis + } \\
\text { Aloe }\end{array}$ \\
\hline $\begin{array}{l}\text { Glomerular } \\
\text { and tubular } \\
\text { necrosis* }\end{array}$ & $0.00 \pm 0.00$ & $0.00 \pm 0.00$ & $1.25 \pm 0.46$ & $1.16 \pm 0.40$ \\
$\begin{array}{l}\text { Tubular } \\
\text { inflammation }\end{array}$ & $0.00 \pm 0.00$ & $0.00 \pm 0.00$ & $0.14 \pm 0.37$ & $0.14 \pm 0.37$ \\
\hline $\begin{array}{l}\text { Parenchymal } \\
\text { edema* } \\
\text { Hyaline and } \\
\text { hematic casts }\end{array}$ & $0.00 \pm 0.00$ & $0.00 \pm 0.00$ & $1.00 \pm 0.00$ & $1.00 \pm 0.00$ \\
\hline
\end{tabular}

${ }^{*} \mathrm{p}<0.05$ (Kruskall-Wallis) Sham and Aloe $x$ Control and Sepsis + Aloe
As regards the histopathological analyses (Table 1), there were no difference between the Sham and Aloe groups and between Control and Sepsis + Aloe groups according to the four parameters analyzed. However, the groups which was performed the CLP had a worse score than no-CLP groups only on glomerular and tubular necrosis and parenchymal edema.

\section{Discussion}

Since the overwhelming inflammatory and immune response during the early stage of sepsis involves a vast array of mediators, controlling this complex inflammatory cascade is critical for sepsis management. The only FDA-approved therapy is the activated drotrecogin alfa or recombinant human activated protein $C[15,16]$. However, the clinical use of this drug is still controversial due to high risk of side effects, such as bleeding and organ disorders

Aloe vera is a plant of the Asphodelaceae (Liliaceae) family typical from dry regions. Among its components, various substances with great biomedical potential, such as: vitamins A, C and E - powerful antioxidants; $\beta$-sisosterol; and anthraquinones, these components present considerable anti-inflammatory properties, especially the acemannan that can stimulate nitric oxide production and reduces the synthesis of oxygen-derived radicals, TNF- $\alpha$, IL1 and IL6; and enzymes which have antibiotic effect [9-12]. So, we hypothesized the Aloe vera might be acting on different inflammatory cascades and applied as adjuvant treatment of sepsis.

The Aloe vera extract show positive effects against sepsis. The oral administration of aloe stimulates the humoral immune system and slows down the action by the cellular pathway avoiding injury caused by exacerbated cellular response [17]. In addition, it promotes areduced colony-forming units in the peritoneal cavity in CLP-induced septic animals, acting as an antiseptic agent [9]. However, it is not possible to confirm in this study, if there is predo- 
minance of antibiotics or anti-inflammatory effects or even synergism between them.

As a consequence of an overactive response to an infection, it can compromise the function of distinct organ systems, leading organ failure, improve the mortality. The kidneys are the most affected organ by sepsis [2, 3]. Histopathologic analysis showed that both groups with CLP-induced have low tissue damage, without difference between animals treated or not. However, the organs were harvested after animals' death, so the Sepsis + Aloe group have a longer bacteremia period and consequent should show a severe histopathologic damages. Therefore, we suggest that aloe protected the kidney function with increased survival rate, but more studies are necessary to study those protective mechanisms.

The only previous study that analyzed the aloe effects on sepsis induced by CLP model demonstrated increase on survival rate and lower histopathological damage in kidney [9], liver and brain, similar to ours with reduction in inflammatory interleukin produces. However, this author used Aloe in gel form and intravenously, different from our method which has used hydroalcoholic extract with higher concentration of anthraquinones and acemannan, the main anti-inflammatory components of the plant and used by gavage [10].

The CLP model of sepsis has been a mainstay of basic sepsis research; Some medicinal plants have been tested in that model [9, 18-21], most with encouraging result; however, the aloe has been used therapeutically for many centuries and has the advantage of clinical studies demonstrating its safety and effectiveness in several diseases [22-24], facilitating the translation. However, more studies are necessary to assess variables of drug administration such as: the best routes of administration (oral, subcutaneous, intraperitoneal or intravenous) and dose and frequency of administration for better results [18, 19].

\section{Conclusion}

1. The application of Aloe vera extract delays mortality of septic mices.

2. The use of Aloe vera not attenuates the kidney injury in sepsis induced by CLP in mices.

\section{Conflict of interest}

None

\section{Financial source}

None

\section{References}

1. Angus DC, Wax RS. Epidemiology of sepsis: an update. Crit Care Med. 2001; 29(Suppl7): S109-16.

2. Huang CT, Tsai YJ, Tsai PR, Yu CJ, Ko WJ. Epidemiology and Outcome of Severe Sepsis and Septic Shock in Surgical Intensive Care Units in Northern Taiwan. Medicine (Baltimore). 2015 Nov;94(47): e2136. doi: 10.1097/MD.0000000000002136. PMID: 26632737.

3. Stoller J, Halpin L, Weis M, Aplin B, Qu W, Georgescu C, Nazzal M. Epidemiology of severe sepsis: 2008-2012. J Crit Care. 2016 Feb;31(1): 58-62. doi: 10.1016/j.jcrc.2015.09.034. PMID: 26601855.

4. Sogayar AM, Machado FR, Rea-Neto A, Dornas A, Grion CM, Lobo SM, Tura BR, Silva CL, Cal RG, Beer I, Michels V, Safi J, Kayath $M$, Silva E. A multicentre, prospective study to evaluate costs of septic patients in Brazilian intensive care units. Pharmaco economics. 2008; 26(5): 425-34. doi: 10.2165/00019053200826050-00006. PMID: 18429658.

5. Westphal GA, Silva E, Salomão R, Bernardo WM, Machado FR. Guidelines for the treatment of severe sepsis and septic shock: hemodynamic resuscitation. Rev Bras Terlntensiva. 2011 Mar; 23(1): 13-23. Doi: 10.1590/S0103-507X2011000100004 . PMID: 25299549.

6. Beale R, Reinhart K, Brunkhorst FM, Dobb G, Levy M, Martin G, Martin C, Ramsey G, Silva E, Vallet B, Vincent JL, Janes JM, Sarwat S, Williams MD. Promoting Global Research Excellence in Severe Sepsis (PROGRESS): lessons from an international sepsis registry. Infection. 2009 Jun; 37(3): 222-32. doi: 10.1007/ s15010-008-8203-z. PMID: 19404580.

7. Teles JM, Silva E, Westphal G, Filho RC, Machado FR. Surviving sepsis campaign in Brazil. Shock. 2008 Oct; 30(Suppl1): 47-52. doi: 10.1097/SHK.0b013e318181a128. PMID: 18704009.

8. Gurib-Fakim A. Medicinal plants: traditions of yesterday and drugs of tomorrow. Mol Aspects Med. 2006 Feb;27(1): 1-93. Mol Aspects Med. 2006 Feb; 27(1): 1-93. PMID: 16105678 
9. Yun N, Lee C, Lee S. Protective effect of Aloe vera on polymicrobial sepsis in mice. Food ChemToxicol. 2009 Jun; 47(6): 1341-8. doi: 10.1016/j.fct.2009.03.013. PMID: 19298839.

10. Choi S, Chung MH. A review on the relationship between aloe vera components and their biologic effects. Semin. Integr. Med. 2003 Mar; 1(1): 53-62.

11. Hamman JH. Composition and applications of Aloe vera leaf gel. Molecules. 2008 Aug; 13(8): 1599-616. PMID: 18794775

12. Kim K, Kim H, Kwon J, LeeS, Kong H, Im SA, Lee YH, Lee YR, Oh ST, Jo TH, Park YI, Lee CK, Kim K. Hypoglycemic and hypolipidemic effects of processed Aloe vera gel in a mouse model of noninsulin-dependent diabetes mellitus. Phytomedicine. 2009 Sep;16(9): 856-63. doi: 10.1016/j.phymed.2009.02.014. PMID: 19303272

13. Walley KR, Lukacs NW, Standiford TJ, Strieter RM, Kunkel SL. Balance of inflammatory cytokines related to severity and mortality of murine sepsis. Infect Immun. 1996 Nov;64(11): 4733-8. PMID: 8890233.

14. Zhou F, Peng ZY, Bishop JV, Cove ME, Singbartl K, Kellum JA. Effects of fluid resuscitation with $0.9 \%$ saline versus a balanced electrolyte solution on acute kidney injury in a rat model of sepsis. Crit Care Med. 2014 Apr;42(4): e270-8. doi: 10.1097/ CCM.0000000000000145. PMID: 24335444.

15. Ranieri VM, Thompson BT, Barie PS, Dhainaut JF, Douglas IS, Finfer S, Gårdlund B, Marshall JC, Rhodes A, Artigas A, Payen D, Tenhunen J, Al-Khalidi HR, Thompson V, Janes J, Macias WL, Vangerow B, Williams MD. Drotrecogin alfa (activated) in adults with septic shock. N Engl J Med. 2012 May; 366(22): 2055-64. doi: 10.1056/NEJMoa1202290. PMID: 22616830.

16. Holder AL, Huang DT. A dream deferred: the rise and fall of recombinant activated protein C. Crit Care. 2013 Mar 12;17(2): 309. doi: 10.1186/cc12533. PMID: 23509922.

17. Vázquez B, Avila G, Segura D, Escalante B. Antiinflammatory activity of extracts from Aloe vera gel. J Ethnopharmacol. 1996 Dec;55(1): 69-75. PMID: 9121170.

18. Botelho NM, Silveira EL, Lopes LN, Santos FAF, Teixeira RKC, da Silva TT. Copaiba oil effect under different pathways in mice subjected to sepsis Acta Cir Bras. 2014 Aug; 29(8): 528-31. doi: 10.1590/S0102-86502014000800008. PMID: 25140595.

19. Lopes LN, Santos FAF, Oliveira LCM, Percario $S$, de Barros CAV, Brito MVH. Copaiba oil effect on induced fecal peritonitis in rats. Acta Cir Bras. 2015 Aug; 30(8): 568-73. doi: 10.1590/ S0102-865020150080000008. PMID: 26352337.

20. Wang H, Li W, Li J, Rendon-Mitchell B, Ochani M, Ashok M, Yang L, Yang H, Tracey KJ, Wang P, Sama AE. The Aqueous Extract of a Popular Herbal Nutrient Supplement, Angelica sinensis, Protects Mice against Lethal Endotoxemia and Sepsis. J Nutr. 2006 Feb; 136(2): 360-5. PMID: 16424112.
21. Hsu DZ, Liu MY. Effects of sesame oil on oxidative stress after the onset of sepsis in rats. Shock. 2004 Dec; 22(6): 582-5. doi: 10.1097/01.shk.0000135254.21699.45. PMID: 15545832.

22. Williams MS, Burk M, Loprinzi CL, Hill M, Schomberg PJ, Nearhood K, O'Fallon JR, Laurie JA, Shanahan TG, Moore RL, Urias RE, Kuske RR, Engel RE, Eggleston WD. Phase III doubleblind evaluation of an aloe vera gel as a prophylactic agent for radiation-induced skin toxicity. Int J RadiatOncolBiol Phys. 1996 Sep 1; 36(2): 345-9. PMID: 8892458

23. Molazem Z, Mohseni F, Younesi M, Keshavarzi S. Aloe vera gel and cesarean wound healing; a randomized controlled clinical trial. Glob J Health Sci. 2014 Aug 31;7(1): 203-9. doi: 10.5539/ gjhs.v7n1p203. PMID: 25560349.

24. Rahmani N, Khademloo M, Vosoughi K, Assadpour S. Effects of Aloe vera cream on chronic anal fissure pain, wound healing and hemorrhaging upon defection: a prospective double blind clinical trial. Eur Rev Med Pharmacol Sci. 2014;18(7): 1078-84. PMID: 24763890.

\section{Publish in International Archives of Medicine}

International Archives of Medicine is an open access journal publishing articles encompassing all aspects of medical science and clinical practice. IAM is considered a megajournal with independent sections on all areas of medicine. IAM is a really international journal with authors and board members from all around the world. The journal is widely indexed and classified Q2 in category Medicine. 